\title{
The mock turtle's tears: ersatz enamel and the hierarchy of media in Pseudo-Kodinos
}

\author{
Warren T. Woodfin \\ Queens College, City University of New York \\ warren.woodfin@qc.cuny.edu
}

The enormous prestige accorded to Byzantine cloisonné enamel seems to have continued into the Palaiologan period, although evidence suggests that its production ceased in the decades after the Fourth Crusade. The medium of the imperial images

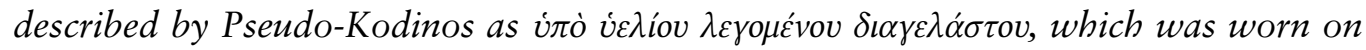
the headgear of thirteen ranks of court officials, is here identified as verre églomisé, reverse painting on glass. A reading of Pseudo-Kodinos' treatise alongside surviving works of art suggests that fourteenth-century Byzantines were consciously using ersatz media in an effort to keep up the appearance of continuity with the empire's more prosperous past.

Keywords: Pseudo-Kodinos; skaranikon; enamel; verre églomisé; hierarchy of media

\section{Enamel as a prestige medium}

In the tenth and eleventh centuries, cloisonné enamel served an important symbolic role in promoting the prestige of the Byzantine court. Enamel was used to adorn the emperor and the furnishings that surrounded him as well as to impress Byzantium's neighbours. ${ }^{1}$

1 On enamels adorning the imperial horse harness, see A. Cutler, 'The industries of art', in A. Laiou (ed.) The Economic History of Byzantium from the Seventh to the Fifteenth Century (Washington, D.C. 2002) 575; enamels as decoration of garments and horse trappings appear in Book IV of the Grottaferrata recension of Digenes Akrites, 11. 222, 240, 792, 822; the Escorial version describes a garment with

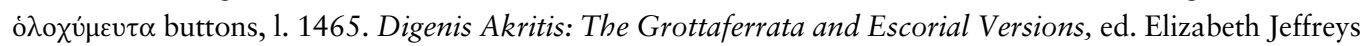
(Cambridge 1998) 80, 112, 114, 346. Dumbarton Oaks preserves a cloisonné enamel pendant, possibly from an imperial loros: S. Boyd in H. Evans and W. Wixom (eds.), The Glory of Byzantium: Art and Culture of the Middle Byzantine Era, A.D. 843-1261 (New York 1997) 212-213, cat. no. 146. On enamel as a diplomatic gift, see M. M. Mango, 'Hierarchies of rank and materials: diplomatic gifts sent by Romanus

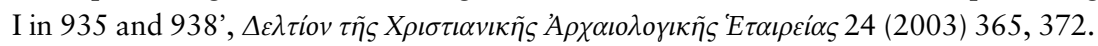



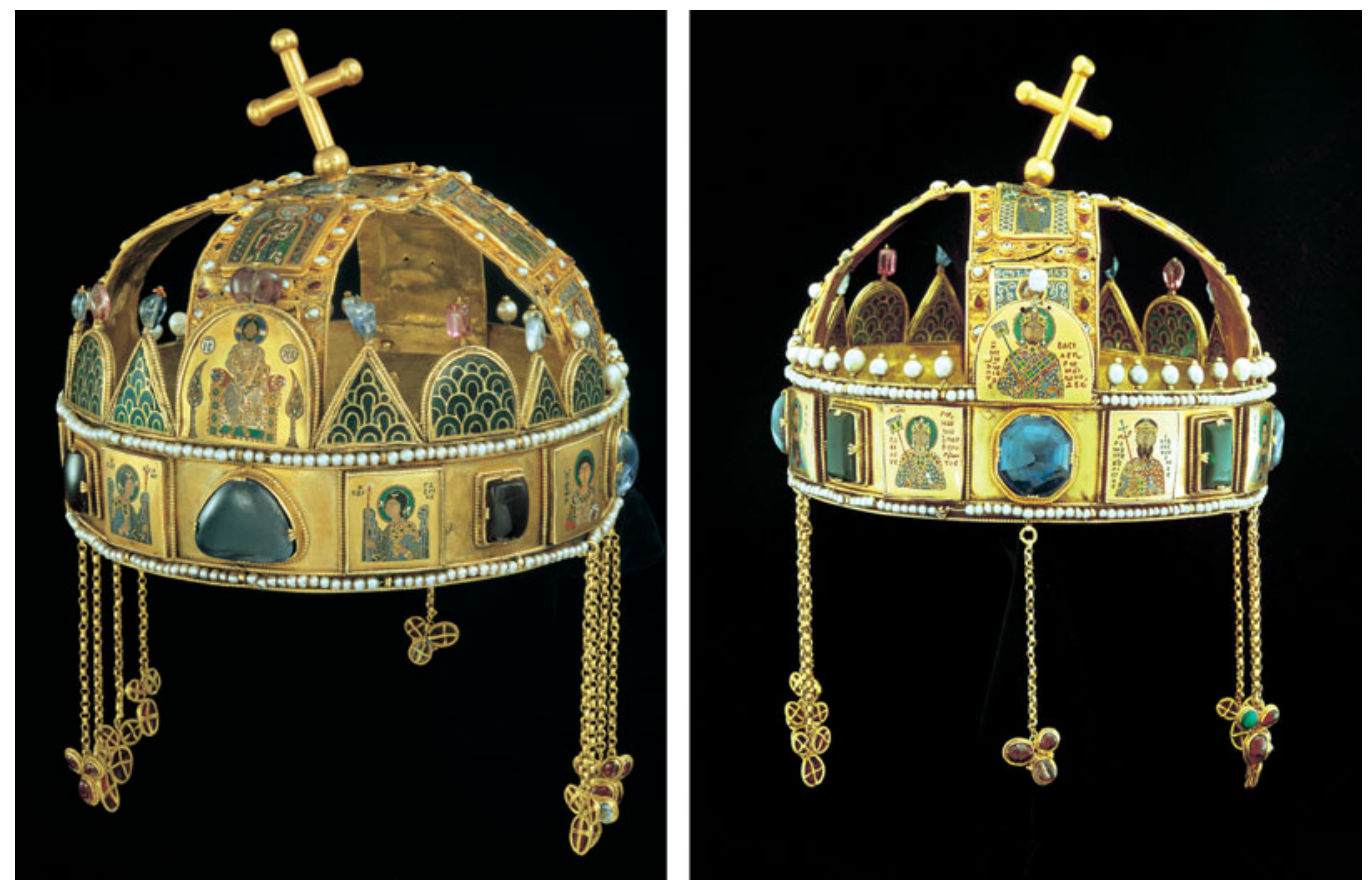

Fig. 1. (Colour online) Holy Crown of Hungary, front and back, with Byzantine enamels of c. 1075, Hungarian National Parliament Building, Budapest. Photography (C) Hungarian Pictures / Károly Szelényi.

In 1045/6, the Fatimid Caliph al-Mustanșir bi-Allāh received a lavish gift from Constantine IX Monomachos that included one hundred 'gold vessels of various kinds inlaid with enamel'. ${ }^{2}$ In the medieval West, gifts of Byzantine enamel might not only provoke wonder at the skill of their manufacture, but might also encode more explicit messages of Byzantine superiority. ${ }^{3}$ On the Holy Crown of Hungary, for example, one can see the almost diagrammatic parallel between Christ flanked by the archangels Michael and Gabriel on the front of the crown and the plaques on the opposite side of the crown showing Michael VII Doukas flanked by his son Constantine and Géza I of Hungary (Fig. 1). ${ }^{4}$ Multiple criteria-position, pose, regalia, and colour of the identifying inscriptions-combine with the virtuosity of the enamel work to drive home the message of

2 M. Hamidullah, ed., Kitab al-Dhakha'ir wa al-Tuhaf (Kuwait 1959), 74-75, par. 82; trans. G. al-Hijjāwī al-Qaddūmī, Book of gifts and rarities (Kitāb al-Hadāyā wa al-Tuḥaf) (Cambridge, MA 1996) 109, par. 82 [n.b.: the correct Hijri year, 437 (not 427), is given in the Arabic text].

3 Notwithstanding the Western European origins of the cloisonné technique, as argued by D. Buckton, "Early Byzantine" enamel in France', in P. Armstrong (ed.), Ritual and Art: Byzantine Essays for Christopher Walter (London 2006) 94-105.

4 On the Crown of Hungary, see most recently C. Hilsdale, 'The social life of the Byzantine gift: the Royal Crown of Hungary re-invented', Art History $31 / 5$ (2008) 602-31, with earlier bibliography at n. 9. 
Byzantine superiority. ${ }^{5}$ By bearing the imperial image, the enamel crown conveyed the implicit idea of the recipient's subordination into a universal political hierarchy under the sway of the emperor in Constantinople.

Byzantine cloisonné enamel continued to command admiration long after the disaster of 1204. During his stop in Venice in 1438, the Byzantine legate to the Council of FerraraFlorence, Sylvester Syropoulos, viewed the Pala d'Oro and admired 'the radiance of the

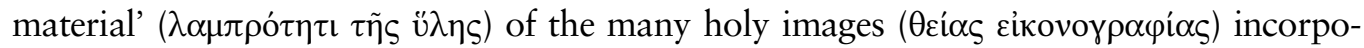

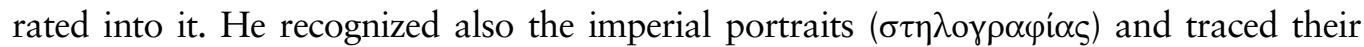
origin-rightly or wrongly-to the Constantinopolitan monastery of Christ Pantokrator. ${ }^{6}$ Along with precious gemstones (for which enamel was itself in some sense a substitute), Byzantine enamels seem to have remained a prized possession and a potential medium of exchange in the fourteenth century. ${ }^{7}$ Actual evidence of the production of cloisonné enamel in fourteenth-century Constantinople, however, is elusive. Production seems to have continued for only a few decades after 1204. There survive three sets of cloisonné enamel plaques that can be plausibly dated to this period: one set adorning a book cover in the Biblioteca Marciana in Venice, ${ }^{8}$ another applied to the frame of an icon of the Virgin at Freising, near Munich, ${ }^{9}$ and the third group on an episcopal mitre now in Stockholm. ${ }^{10}$ After the middle of the thirteenth century little-if any-true cloisonné enamel was

5 H. Maguire in Evans and Wixom (eds.), Glory of Byzantium, 188; C. Jolivet-Lévy, 'L'apport de l'iconographie à l'interprétation de la "Corona Graeca",' Acta Historiae Artium 43 (2002) 22-32, especially 22-27; Hilsdale, 'Social life of the Byzantine gift', 618-619. On the significance of signature colours for rank, see A. Failler, 'Les insignes et la signature du despote', Revue des études byzantines 40 (1982) 172185; R. Guilland, Recherches sur les institutions byzantines (Berlin 1967) 36.

6 Sylvester Syropoulos, Les 'Mémoires' du Grand Ecclésiarche de l'Église de Constantinople sur le Concile de Florence (1438-1439), ed. V. Laurent (Paris 1971) 222-223; H. Klein, 'Refashioning Byzantium in Venice, ca. 1200-1400', in H. Maguire and R. S. Nelson (eds.), San Marco, Byzantium, and the myths of Venice (Washington, D.C. 2010) 193-196; P. Hetherington, 'Byzantine and Russian enamels in the treasury of Hagia Sophia in the late fourteenth century', Byzantinische Zeitschrift 93 (2000), repr. in Enamels, crowns, relics and icons (Farnham 2008) study V, 136; Hetherington, 'Byzantine cloisonné enamel: production, survival and loss', Byzantion 76 (2006), repr. in Enamels, crowns, relics and icons, study I, 197, n. 110.

7 P. Hetherington, 'A purchase of Byzantine relics and reliquaries in fourteenth-century Venice', Arte Veneta 37 (1983) 9-30, repr. in Enamels, crowns, relics and icons, study VII, 1-38, especially 26-30; Klein, 'Refashioning Byzantium in Venice', 200-206.

8 K. Wessel, Byzantine Enamels from the $5^{\text {th }}$ to the $13^{\text {th }}$ Century (Greenwich, CT 1967) 196-200; M. E. Frazer in D. Buckton (ed.), The Treasury of San Marco, Venice (Milan 1984) 176-178.

9 Wessel, Byzantine Enamels, 195-196; M. Vassilaki, 'Praying for the salvation of the empire?' in M. Vassilaki (ed.), Images of the Mother of God: perceptions of the Theotokos in Byzantium (Aldershot 2005) 263-274; D. Buckton, 'Byzantine enamels in Bavaria', Mitteilungen zur spätantiken Archäologie und byzantinischen Kunstgeschichte 2 (2000) 97-99. The author would like to thank the Director of the Diözesanmuseum Freising, Dr. Christoph Kürzeder, for the opportunity to examine the enamels of the Freising 'Lukasbild'.

10 This group is attributed to a workshop operating in Latin-ruled Constantinople in the decades immediately after the Fourth Crusade. P. Hetherington, 'The enamels on a mitre from Linköping Cathedral, and art in thirteenth-century Constantinople', in Enamels, Crowns, Relics and Icons, study XI, 1-16. 
produced in Byzantium. ${ }^{11}$ Although sets of figural cloisonné medallions were used to ornament the frames of icons, as with the icon of the Virgin in Freising, when they appear in Palaiologan settings, such enamels were presumably reused from earlier objects. For instance, the set of cloisonné medallions on the frame of a fourteenth-century mosaic icon of St. John the Theologian at the Great Lavra can be demonstrated to come from an earlier icon of John the Forerunner. ${ }^{12}$

The glass flux used by the Byzantines for translucent enamel had a melting point of about $1000{ }^{\circ} \mathrm{C}$, and thus gold, which remains solid well beyond that temperature, was the preferred metal for the technique. ${ }^{13}$ By the end of the thirteenth century, however, the imperial treasury was chronically short of gold bullion, so much so that the coemperor Michael IX had to resort to melting down household gold and silver wares for coin to raise an army in $1304 .^{14}$ The civil wars of the fourteenth century only exacerbated the already existing shortage. Numismatic evidence points to a steady decline in the gold content of the byperpyron over the reigns of Michael VIII and Andronikos II, and the millennium-long tradition of Byzantine gold coinage reached its end with the reign of John VI Kantakouzenos. ${ }^{15}$ Given the financial straits of the empire in its final

11 Anastassios Antonaras has recently redated a Byzantine cloisonné earring or temple pendant with enamelled geometric ornament on copper alloy to the Middle Byzantine period, revising his previous, Palaiologan attribution: A. Antonaras, 'Late Byzantine jewellery from Thessaloniki', in A. Bosselmann-Buickbie (ed.), Neue Forschungen zur spätbyzantinischen Goldschmiedekunst, forthcoming; Antonaras, 'The production and uses of glass in Byzantine Thessaloniki', in C. Entwistle and L. James (eds.), New Light on Old Glass: Recent Research on Byzantine Mosaics and Glass (London 2013) 125, pl. 23. Further, Christopher Walter has proposed a late thirteenth century date for an icon in the Hermitage of cloisonné enamel on copper: C. Walter, 'Saint Theodore and the Dragon', in C. Enwistle (ed.), Through a Glass Brightly: Studies in Byzantine and Medieval Art and Archaeology Presented to David Buckton (Oxford 2003) 95-106. I leave aside from discussion here the icon of St. Demetrios in Berlin, which has been attributed to the early thirteenth century, but which is not executed in the cloisonné technique. D. Buckton, 'The gold icon of St. Demetrios', in J. Ehlers and D. Kötzsche (eds.), Der Welfenschatz und sein Umkreis (Mainz 1998) 277-86.

12 A. Grabar, Les revêtements en or et en argent des icones byzantines du Moyen Âge (Venice 1975) 62, figs. 71, 72, cat. no. 33; M. Chatzidakis, 'Une icone en mosaïque de Lavra', Jahrbuch der Österreichischen Byzantinistik 21 (1972) 73-81, especially 79-81.

13 D. Buckton, 'Theophilus and enamel', in D. Buckton and T. A. Heslop (eds.), Studies in Medieval Art and Architecture Presented to Peter Lasko (Dover, NH 1994) 8-9; Buckton, 'Enameling on gold: a historical perspective', Gold Bulletin 15 (1982) 103.

14 George Pachymeres, Relations historiques, ed. A. Failler, 5 vols. (Paris 1984-2000) IV, 491; cited in K. Smyrlis, 'Financial crisis and the limits of taxation under Andronikos II Palaiologos (1282-1321)', in D. Angelov and M. Saxby (eds.), Power and Subversion in Byzantium: Papers from the $43^{\text {rd }}$ Spring Symposium of Byzantine Studies, Birmingham, March 2010 (Aldershot 2013) 72.

15 P. Grierson, Catalogue of the Byzantine Coins in the Dumbarton Oaks Collection and in the Whittemore Collection (Washington 1999) V.1-2, 1, 128-134; for an iconographic analysis of the last Palaiologan gold issues, see C. Hilsdale, Byzantine Art and Diplomacy in an Age of Decline (Cambridge 2014) 185-197. On the metallic content of the Palaiologan gold coinage, see C. Morrisson, J.-N. Barrandon, and S. Bendall, 'Proton activation and XRF analysis: an application to the study of the alloy of Nicean and Palaeologan hyperpyra issues', in W. A. Oddy (ed.), Metallurgy in Numismatics 2 (London 1988) 24-25, repr. in C. Morrisson, Monnaie et finances à Byzance: analyses, techniques (Aldershot 1994), study no. XI. 
centuries, it must have been difficult to acquire sufficient gold to sustain (or revive) the regular production of translucent cloisonné enamels. ${ }^{16}$ One possible solution was to switch to silver as the supporting metal, using a limited palette of opaque enamels with relatively low melting points. The fourteenth-century silver frame of the Mandylion icon in Genoa (recorded there by 1388) uses a combination of opaque enamel and niello set in the concavities of figures worked in repoussé. This technique has been interpreted by Paul Hetherington as a one-off solution by an artist otherwise unfamiliar with working in enamel. ${ }^{17}$ These narrative scenes framing the Genoa Mandylion are the sole group of figural enamels that can be securely attributed to a fourteenth-century Byzantine artist. Although fine basse taille enamels on silver ornament a number of objects produced for Byzantine patrons, such as the chalice and paten of Thomas Komnenos Prelubović, Despot of Ioannina (1367-1384), it is likely that these commissions were carried out by Venetian artists. ${ }^{18}$ Far more typical of late Byzantine production is the rather dull green pseudo-champlevé enamel seen on the handle of a copper censer ( $k a t$ zion) preserved in the Benaki Museum. ${ }^{19}$ Green or blue-green enamel was also used occasionally to ornament the repoussé frames and revetments of Palaiologan icons. ${ }^{20}$ The Freising icon of the Virgin, which carries on its frame the series of thirteenth-century cloisonné roundels already mentioned, also received a silver-gilt revetment towards the end of the fourteenth century. This seems to have formed part of a renovation to fit the icon as a suitable gift for Manuel II's fund-raising journey through Western Europe, during which he presented it to Giangaleazzo Visconti of Milan. ${ }^{21}$ The revetment's

16 On precious metal supplies and the debasement of currency in late Byzantium, see C. Morrison, 'Byzantine money: its production and circulation', in Laiou (ed.) Economic History of Byzantium, 942-946. Suitable glass for transparent enamel flux may also have been in short supply. M. Vassilaki, 'The absence of glass: talking about the mosaics at Porta Panagia in Thessaly, Greece', in Entwistle and James (eds.), New Light on Old Glass, 229-233.

17 P. Hetherington, 'The frame of the Sacro Volto icon in S. Bartolomeo degli Armeni, Genoa: the reliefs and the artist', Cahiers Archéologiques 50 (2002) 175-177; for a more positive view of the technique, see F. Dell'Acqua, 'Borders of experimentalism: glass in the frame of the Genoa Mandylion', in Entwistle and James (eds.), New Light on Old Glass, 234-241.

18 K. Loverdou-Tsigarida, 'Byzantine small art works', in The Holy and Great Monastery of Vatopaidi, 2 vols. (Mt. Athos 1998) II, 477-481, figs. 426-430.

19 A. Ballian in Evans (ed.), Byzantium: Faith and Power, 128-129, cat. no. 65. David Buckton, "'All that

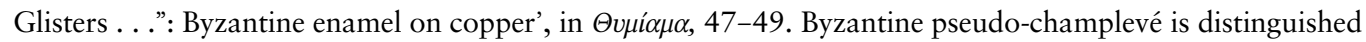
by the use of a second plaque, cut to shape, over the base plaque.

20 Grabar, Revêtements en or et en argent, 38-39, 41-43, 49-52, 60, figs. 31-36, 39-41, 43-44b, 47-52, $66-67$, cat. nos. 12, 13, 16, 21, 31. In the case of the frames of the mosaic icons in Florence, Grabar highlights the discrepancy in quality between the mosaics themselves-a high point of Palaiologan art-and the rather mass-produced enameled plaques (ibid., 60).

21 Hilsdale, Byzantine Art and Diplomacy, 231-235; Vassilaki, 'Praying for the salvation of the empire?' 263-270. 
inscriptions resemble enamel, but according to an analysis by David Buckton, they actually contain pigment in an organic binding medium rather than glass flux. ${ }^{22}$ Given that these additions to the icon were likely part of an imperial commission, one imagines that proper enamel would have been used if it had been at all feasible. Rather than shifting their attention to other art forms, Byzantine artists and patrons seem to have sought ways to compensate for the loss of the necessary materials and skills for the manufacture of cloisonné enamel. In other words, the Palaiologan period witnessed an attempt to keep up appearances, extending the life of a prestige medium by other means.

\section{Pseudo-Kodinos and the Skaranikon}

The ceremonial manual on the offices of the Byzantine court, long known under the name of Pseudo-Kodinos, describes the use of luxury media at the highest levels of the Palaiologan court. The testimony of Pseudo-Kodinos is especially interesting in that he treats not only costume and regalia, but also the imperial image which is systematically deployed on the headgear known as the skaranikon. His treatise thus establishes a relationship between the imperial likeness as a sign of office and rank in court ceremonial and the artistic media in which that image was fashioned. The text not only gives an insight into hierarchy of media in the Palaiologan period, but also a sense of the place of ersatz techniques within this system.

The composition of the text of Pseudo-Kodinos' treatise is dated by Verpeaux on internal evidence to the reign of John VI Kantakouzenos, who is alluded to at several points in the text, or to the reign of his successor, John V Palaiologos. ${ }^{23}$ The most recent research on the treatise has confirmed Verpeaux's dating (shortly after 1347, but incorporating some earlier material) and underlined the connections between certain features of the text and John VI's reign. ${ }^{24}$ The treatise differs from several other fourteenthcentury lists of precedence in the ordering of the ranks of the first seven offices. ${ }^{25}$ Since the discussion here concerns the internal logic of Pseudo-Kodinos' costume system, the ordering of the ranks will follow his numbering, in which the first seven ranks after the

22 Vassilaki, 'Praying for the salvation of the empire?' 268; D. Buckton, 'Enamelled metal icons in the twelfth and thirteenth centuries', in M. Vassilaki (ed.), Byzantine Icons: Art, Technique and Technology (Herakleion 2002) 315-316; Buckton, 'Byzantine enamels in Bavaria', 97-99.

23 Kantakouzenos is repeatedly mentioned by name in the text. De officiis, ed. R. Macrides, J. A. Munitiz, and D. Angelov, Pseudo-Kodinos and the Constantinopolitan Court: Offices and Ceremonies (Aldershot 2013) 26-27, 50-51, 248-249, 271; De officiis, ed. J. Verpeaux, Pseudo-Kodionos, Traité des offices (Paris 1966) 135, 136, 152, 276; Verpeaux's dating of the text is found at 25-35.

24 Macrides et al., Pseudo-Kodinos, 1-10, 17-18. On the relation of the treatise to John Kantakouzenos, see further N. Gaul, 'The partridge's purple stockings: observations on the historical, literary and manuscript context of Pseudo-Kodinos' handbook on court ceremonial', in M. Grünbart (ed.), Theatron. Rhetorische Kultur in Spätantike und Mittelalter (Berlin 2007) 69-103.

25 See the discussion and tabular presentation of the several surviving orders for precedence in Macrides et al., Pseudo-Kodinos, 280-289, 296, Table I, 455-464, Table IV, and further discussion in Gaul, 'The partridge's purple stockings', $74-85$. 
emperor are (1) despotes, (2) sebastokrator, (3) caesar, (4) megas domestikos, (5) panhypersebastos, (6) protovestiarios, and (7) megas doux. ${ }^{26}$

The treatise explicates in order of rank the regalia associated with each office. On the occasions of greatest solemnity, the higher officials of the court wore a silk kabbadion-a long-sleeved, full-length garment fastening down the length of the front and derived, as its name implies, from the kaftans of the Turkic world. ${ }^{27}$ Along with the $k a b$ badion, the most important article of dress of the courtier was his feast-day headgear, the skaranikon. ${ }^{28}$ Shoes of appropriate colour to the rank of the wearer, along with rods of various sorts held in the hand, completed the ensemble. ${ }^{29}$ These descriptions and their parallels in the visual arts paint a vivid picture of a court clothed in silk and gold. The impression of precise order and courtly luxury given by the enumeration of these insignia stands in stark relief, however, against the background of social upheaval and economic deprivation occasioned by the civil wars of the fourteenth century. The famous passage from Nikephoros Gregoras on the coronation of John VI Kantakouzenos at the palace of Blachernai in 1347 records the substitutions of gilded ceramic for precious metal banqueting vessels and of glass pastes for the crown jewels of the empire, which had been pawned by Anna of Savoy in 1343 and never redeemed. ${ }^{30}$ Even PseudoKodinos' own account is a witness to the scarcity of precious metals. At the imperial coronations, the emperor is said to distribute small bags of coins, apokombia, to the assembled crowd, who presumably take them away. ${ }^{31}$ On the other hand, at the annual largitio ceremony of Christmas Eve, the megas domestikos distributes plates of silver

26 Verpeaux, Pseudo-Kodinos, 133-140. The numbering of the offices by rank, used here for the sake of clarity, was used in the Palaiologan period as well, as witnessed by George Sphrantzes, Cronaca, ed. R. Maisano, Corpus Fontium Historiae Byzantinae XXIX (Rome 1990) 124; cited in Gaul, 'The partridge's purple stockings', 98 .

27 From the Persian qabā. M. Parani, Reconstructing the Reality of Images (Leiden 2003) 58, 60; Parani, 'Cultural identity and dress: the case of late Byzantine ceremonial costume', Jahrbuch der Österreichischen Byzantinistik 57 (2007) 106.

28 The older view endorsed by N. Kondakov ('Les costumes orientaux à la cour byzantine', Byzantion 1 [1924] 16) that the skaranikon represents a later form of the skaramangion, which he interprets as a riding coat, is not sustainable. On the headgear and its terminology, see Parani, Reconstructing the Reality of Images, 69-70; Macrides et al., Pseudo-Kodinos, 332-336.

29 Macrides et al., Pseudo-Kodinos, 36-39, 44-45, 46-47, 52-53, 174-175, 244-245; De Off., ed. Verpeaux, 143-144, 148. On coloured shoes as a mark of court office, see Macrides et al, 175, note 487; cf. the stipulation at 100-101, that the Vardariot guard, who are not court officials per se, wear black shoes.

30 Nikephoros Gregoras, Byzantina Historia, ed. L. Schopen, II (Bonn 1830) 788-789; P. Hetherington, 'The jewels from the crown: symbol and substance in the later Byzantine imperial regalia', Byzantinische Zeitschrift 96 (2003) 157. John V's later attempt to trade the island of Tenedos for the return of the stones failed. R.-J. Loenertz, 'Jean V Paléologue à Venise (1370-1371)', Revue des études byzantines 16 (1958) 217-232.

31 Macrides et al., Pseudo-Kodinos, 214-217, 238-239; Verpeaux, De off., 255, 271; Hilsdale, Byzantine Art and Diplomacy, 273-276. 
and gold to the assembled courtiers, but everyone apart from the megas domestikos himself is expected to give them back to the imperial treasury at the end of the ceremony. ${ }^{32}$ The ceremonial distribution of 'gifts' that are immediately returned suggests the limits of imperial wealth. ${ }^{33}$ Despite the impression of courtly magnificence and order in Pseudo-Kodinos, one must bear in mind the background of material poverty against which he was writing. ${ }^{34}$

One might almost see Pseudo-Kodinos' meticulous delineation of the ceremonial dress of the court as a reactive emphasis on taxis over against the economic decline and political disorder that followed the second civil war. Under Andronikos III, according to the scandalized Nikephoros Gregoras, the court had presented a kind of sartorial free-for-all, with courtiers, regardless of their seniority, wearing headgear 'of many and diverse kinds and unusual forms according to the will of each. ${ }^{35}$ Gregoras interpreted this disorder in dress as a precursor to the disastrous conflicts that would follow Andronikos III's death. The vestimentary system laid out in Pseudo-Kodinos puts aside such frivolity in favour of a precise correlation between each dignity and its insignia. Every rank has two hats, generally the skiadion and skaranikon, of prescribed materials and decoration. The skaranikon of each rank is carefully defined as to five criteria: its overall material, its colour, the presence or absence of an imperial portrait, the pose of the imperial figure, and finally, the medium in which those images are executed. Three basic types of skaranikon are described in the text. The most elite version, pertaining to the

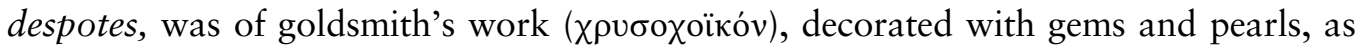
seen on the fragmentary portrait of the despot Theodore I Palaiologos at the Aphendiko in Mistra (Fig. 2). ${ }^{36}$ From the megas domestikos (rank 4) to the protoierakarios

32 Macrides et al., Pseudo-Kodinos, 160-163; Verpeaux, De off., 216-217; Gaul, 'The partridge's purple stockings', 77-78.

33 On the roga of court officials and its replacement by other means of compensation in the Komnenian era, see N. Oikonomides, 'Title and income at the Byzantine court', in Maguire (ed.), Byzantine Court Culture, 210-215; Oikonomides, 'The role of the Byzantine state in the economy', in Laiou (ed.), Economic History of Byzantium, 993-995, 1040-1041. On payments to courtiers in the Palaiologan period, see Macrides et al., Pseudo-Kodinos, 312-315.

34 'In the 1340s, a conjunction of factors had catastrophic effects on the population, the agriculture, and the economy of exchange.' A. Laiou, 'The Byzantine economy: an overview', in Laiou (ed.), Economic History of Byzantium, 1160.

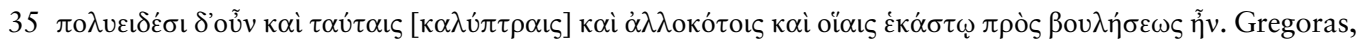
Byzantina Historia, ed. L. Schopen, I (Bonn 1829) 568. The passage is discussed in Macrides et al., PseudoKodinos, 1-3.

36 Macrides et al., Pseudo-Kodinos, 40-41, n. 35; Verpeaux, De off., 145.23-146.2. Pseudo-Kodinos pleads ignorance as to the type of skaranikon appropriate to sebastokrators and caesars, although the list of

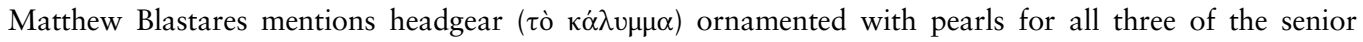
dignities. De Off., 147.1-3; Traité des offices, 320.7-9. For the fresco, see J. Ebersolt, Les arts somptuaires de Byzance: étude sur l'art impérial de Constantinople (Paris 1923) 125, fig. 58. 


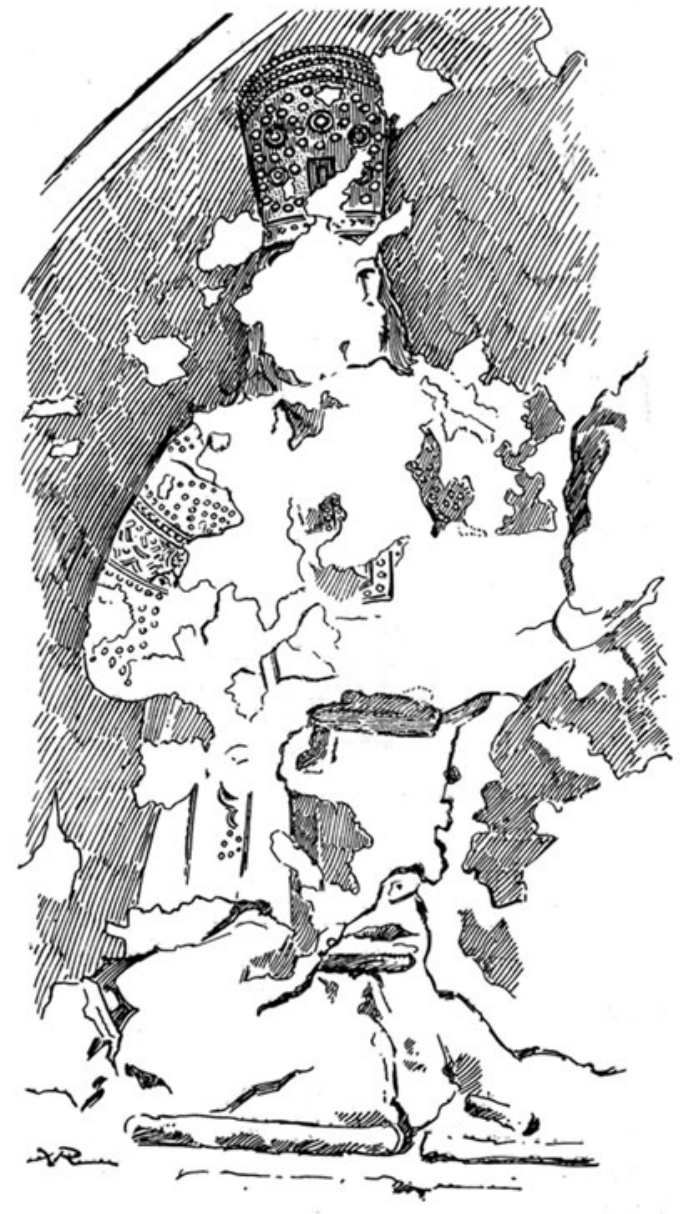

Fig. 2. Despot Theodore I Palaiologos, fresco, late $14^{\text {th }}$ century, Aphendiko, Mistra. Drawing after J. Ebersolt, Les arts somptuaires de Byzance: étude sur l'art impérial de Constantinople (Paris 1923) 125, fig. 58.

(rank 48), the skaranikon is of silk ornamented with gold embroidery over its surface. Finally, from the rank of megas diermeneutes (50) to the papias (80), the skaranikon is of red napped fabric $(\chi \alpha \dot{\alpha} \sigma \delta \varepsilon \sigma v)$ without embroidered decoration. ${ }^{37}$

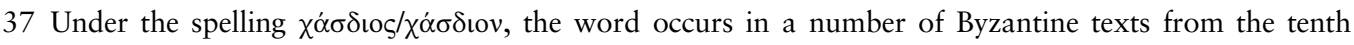
century onward. See Du Cange, Glossarium, s.v., cols. 1739-1740; M. Mavroudi, A Byzantine Book on Dream Interpretation: The Oneirocriticon of Achmet and its Arabic Sources (Leiden 2002) 65, n. 14; 471. Macrides et al., Pseudo-Kodinos, 64, 1. 8. Both Verpeaux and Macrides have interpreted the term chasdeon to mean velvet (Verpeaux, Traité des Offices, 163; Macrides et al., Pseudo-Kodinos, 65, n. 98), but this presents a potential difficulty with the relative value of materials. Fourteenth-century Italian accounts give values for plain silk velvet at 25 soldi per braccio, whereas unpatterned silks such as might have been used for the embroidered skaranika of the higher members of the court sold for $8-14$ soldi per braccio. L. Monnas, Merchants, Princes and Painters: Silk Fabrics in Italian and Northern Paintings 1300-1550 (New Haven 2008) 322, Table 3. Felt offers an attractive alternative interpretation, as already suggested by Macrides et al., Pseudo-Kodinos, 334. 
Colour, furthermore, is used systematically to differentiate groups among the wearers of the silk skaranika (rather confusingly referred to as 'gold skaranika' by Pseudo-

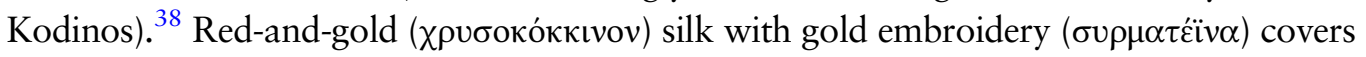
the skaranika of the ranks from the megas domestikos (4) to the megas stratopedarches (10), while the ranks from the megas primmikerios (11) to the parakoimomenos tou koi-

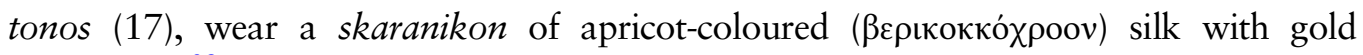
embroidery. ${ }^{39}$ The colour changes again with the logothetes tou genikou (18) through the eparchos (23), who wear gold-and-white (

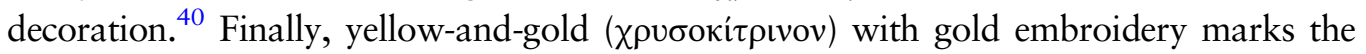
skaranikon of the megas droungarios tes vigles (24) through the protoierakarios (48). ${ }^{41}$ Whereas the Komnenoi used colour as a mark of rank for the new dignities created or revamped for members of the imperial family, the Palaiologan period marks the first systematic extension of the concept to embrace nearly the whole of the court and its dress. ${ }^{42}$ One sees an analogous but not identical system of colour in the prefatory miniatures added c. 1330 to the Lincoln College Typikon. ${ }^{43}$ Each of the men of the court is shown wearing the kabbadion and a skaranikon with the imperial portrait. ${ }^{44}$ The colour of the kabbadion-red, green, or apricot-varies with their rank, whereas the skaranikon is identical for all the figures that wear it (Fig. 3). ${ }^{45}$ The inverse is true in the text of PseudoKodinos: while the skaranikon varies in colour according to the wearer's rank, only the highest officials are assigned a designated colour of kabbadion, ${ }^{46}$ while the other courtiers

38 Macrides et al., Pseudo-Kodinos, 332-333.

39 Pseudo-Kodinos gives a brief excursus on the significance of the colour as an intermediate shade between red and white (with the implication that it would signify intermediate ranks). Macrides et al., PseudoKodinos, 54-55; Verpeaux, De off., 155.3-8.

40 Macrides et al., Pseudo-Kodinos, 56-57; Verpeaux, De off., 156.24-25.

41 Macrides et al., Pseudo-Kodinos, 58-59; Verpeaux, De off., 158.14-17.

42 Failler, 'Les insignes', 171-186; B. Ferjančić, 'Sevastokratori u Vizantiji', Zbornik Radova 11 (1968) 191; A. Kazhdan, 'Sevastokratory i despoty v Vizantii XII v.: Neskol'ko dopolnenii', Zbornik Radova 14/15 (1973) 41-44; Hilsdale, 'Social life of the Byzantine gift', 618, 629, n. 49. The 'frog-green' shoes of the protovestiarios are mentioned in the context of the reign of Alexios Angelos by Niketas Choniates, Historia, ed. J.-L. van Dieten (Berlin 1975) 507.

43 The fundamental study of the manuscript is I. Hutter, 'Die Geschichte des Lincoln College Typikons', Jahrbuch der Österreichischen Byzantinistik 45 (1995) 79-114. See most recently N. Gaul, 'Writing "with joyful and leaping soul": sacralization, scribal hands, and ceremonial in the Lincoln College Typikon', Dumbarton Oaks Papers 69 (2015) 243-271, with previous bibliography.

44 The exception is the sebastokrator Constantine, the younger half-brother of emperor Michael VIII, who wears the diadem (stephanos) and mantle (tamparion) befitting his rank. Prospographisches Lexikon der Palaiologenzeit, ed. E. Trapp (Vienna 1976-1992) IX, no. 21498; Parani, 'Cultural identity and dress', 119120.

45 Despite the fact that the manuscript is the foundation document of a nunnery, there is no variation among the women's court dress, which conveys only general membership in the imperial elite rather than precise rank. Hutter, 'Geschichte des Lincoln College Typikons', 86.

46 Macrides et al., Pseudo-Kodinos, 42-43 (despotes), 44-45 (sebastokrator), 46-47 (caesar), 50-51 (megas domestikos), 53, note 68 (megas doux); De Off., ed. Verpeaux, 146-154. 


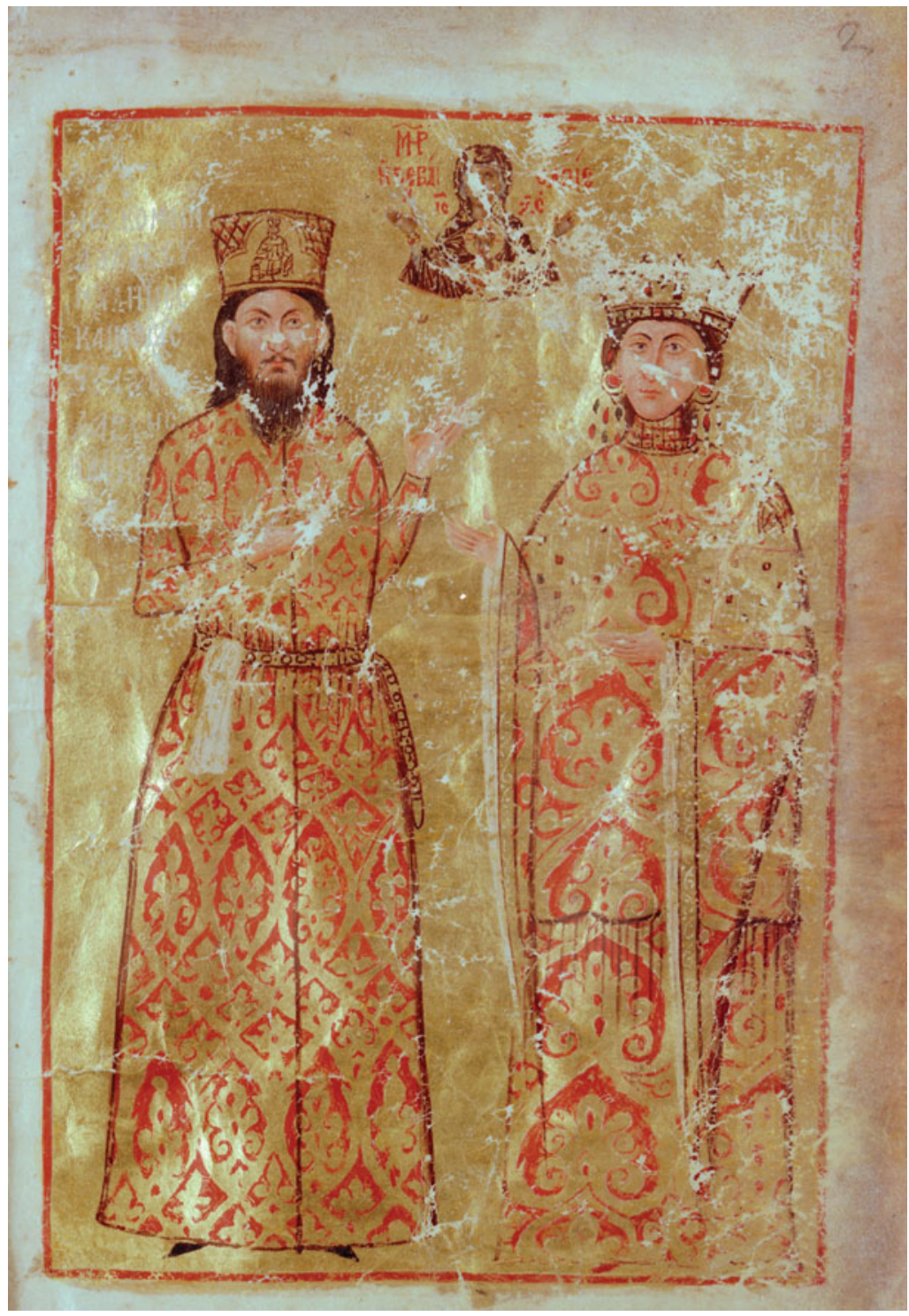

Fig. 3. (Colour online) Megas Stratopedarches John Synadenos and Theodora Palaiologina, Typikon of the Nunnery of Bebaia Elpis, Lincoln College, Oxford, MS Gr 35, fol. 2r. Photograph @ Lincoln College, Oxford, 2017. 
from the megas doux (7) to the parakoimomenos tou koitonos (17) are allowed to choose

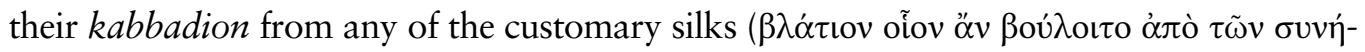
$\theta \omega v.) .{ }^{47}$ With the kabbadion as such an ambiguous signifier in the manual, the headgear assumes far greater importance as a mark of rank.

The imperial portrait, a feature of the thirty-seven highest ranks (excluding the despotes, sebastokrator, and caesar), is the most striking means of displaying hierarchy among the wearers of the 'gold skaranika'. The pose of the portraits varies according to rank: a standing image of the emperor, flanked by images of angels, appears on both the front and back of the skaranikon of the megas domestikos (4), panhypersebastos (5), and protovestiarios (6). ${ }^{48}$ The skaranika of the megas doux (7) through the eparchos (23) lack the angels, but have the images of the emperor standing in front and enthroned behind. ${ }^{49}$ From the megas droungarios tes vigles (24) down to the protoierakarios (48), the skaranikon shows the emperor seated on an elevated throne on the front and on horseback behind. ${ }^{50}$ These portrait types show a gradation from the emperor's most deferential pose-standing, as he would be seen if depicted in the company of Christ or the angels-to his most imposing postures, enthroned or seated on horseback. ${ }^{51}$ In other words, the emperor's image becomes increasingly imposing in inverse proportion to the dignity of its wearer. ${ }^{52}$ A tabular presentation Pseudo-Kodinos' information on the headgear makes clear that some of the shifts in pose coincide with the changes in the colour of the hat's fabric and in the medium of the portraits, while others do not (Table 1).

Unfortunately, it is impossible to parallel this hierarchy of poses in any surviving images of courtiers' skaranika. No known work of art depicts a skaranikon with the standing imperial figure stipulated for ranks 4 to 23. The hats shown in the Lincoln College Typikon uniformly display an enthroned emperor. The donor portrait of Constantine Akropolites on the silver-gilt repoussé frame of an icon of the Hodegetria in Moscow, among the earliest representations of the skaranikon with the imperial portrait, shows a bust-length imperial portrait, which is not among the poses listed by

47 Those with the rank of logothetes tou genikou (18) and below wear kabbadia of the silks 'usually

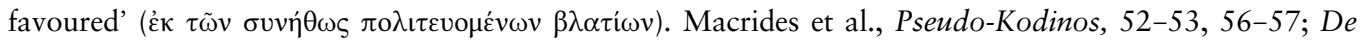
Off., 153.18-154.1, 156.22-23.

48 Macrides et al., Pseudo-Kodinos, 50-51; De off., 152.1-9.

49 Macrides et al., Pseudo-Kodinos, 52-53; De off., 153.14-17.

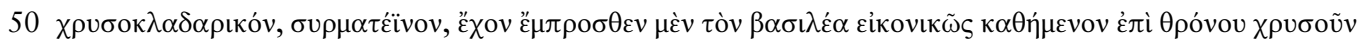

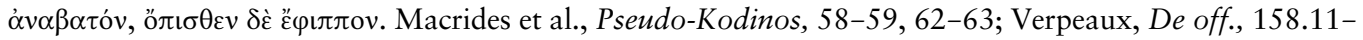
20, 162.7 .

51 The emperor and empress alone ride on horseback for the return to the palace following the emperor's coronation, the others go on foot, 'from the despotes to the humblest.' Macrides et al., Pseudo-Kodinos, 236-237; De off., 269.23-25. For the emperor's receiving petitions on horseback, see the discussion in R. Macrides, "The reason is not known." Remembering and recording the past: Pseudo-Kodinos as a historian', in P. Oderico et al. (eds.), L'écriture de la mémoire. La littérarité de l'historiographie (Paris 2006) 327-328.

52 Conversely, the absence of the imperial image from the 'jewelled skaranika' might be interpreted as a mark of deference to the near-imperial rank of their wearers. 
Table 1. The 'gold skaranika' according to Pseudo-Kodinos

\begin{tabular}{|c|c|c|c|c|}
\hline $\begin{array}{l}\text { Rank } \\
\text { Number }\end{array}$ & Title & Colour of skaranikon & Pose of imperial portraits & Material of imperial portraits \\
\hline 4 & Megas Domestikos & Red and gold & $\begin{array}{l}\text { Standing in front and in back, } \\
\text { flanked by angels in pearled roundels }\end{array}$ & 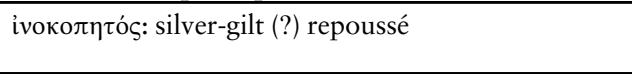 \\
\hline 5 & Panhypersebastos & " & " & $" 1$ \\
\hline 6 & Protovestiarios & " & $" 1$ & $" 1$ \\
\hline 7 & Megas Doux & "1 & Standing in front, enthroned in back & 11 \\
\hline 8 & Protostrator & " & " & 11 \\
\hline 9 & Megas Logothetes & " & $" 1$ & $" 1$ \\
\hline 10 & Megas Stratopedarches & " & " & $" 1$ \\
\hline 11 & Megas Primmikerios & Apricot and gold & $" 1$ & 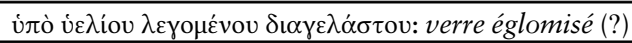 \\
\hline 12 & Megas Konostaulos & " & $" 1$ & " \\
\hline 13 & Protosebastos & " & $" 1$ & 11 \\
\hline 14 & Pinkernes & " & $" 1$ & 11 \\
\hline 15 & Kouropalates & " & 11 & " \\
\hline 16 & Parakoimomenos tes Sphendones & "1 & "1 & " \\
\hline 17 & Parakoimomenos tes Koitonos & " & " & $" 1$ \\
\hline 18 & Logothetes tou Genikou & White and gold & " & $"$ \\
\hline 19 & Protovestiarites & " & " & $" 1$ \\
\hline 20 & Domestikos tes Trapezes & " & " & $" 1$ \\
\hline 21 & Epites Trapezes & " & " & 11 \\
\hline 22 & Megas Papias & " & " & " \\
\hline 23 & Eparchos & “ & $" 1$ & " \\
\hline 24 & Megas Droungarios tes Vigles & Yellow and gold & Enthroned in front, equestrian in back & $\chi \rho \nu \sigma о к \lambda \alpha \delta \alpha \rho ı$ ќv: gold embroidery \\
\hline 25 & Megas Hetaireiarches & "I & $" \prime$ & 11 \\
\hline 26 & Megas Chartoularios & " & " & 11 \\
\hline$\ldots^{\mathrm{a}}$ & $\ldots$ & $\ldots$ & $\ldots$ & $\ldots$ \\
\hline 48 & Protoierakarios & $" 1$ & $" 1$ & " \\
\hline
\end{tabular}

${ }^{a}$ Note that for ranks 27, 28, 30, 39, 40, 44, 47, and 49, Pseudo-Kodinos prescribes a turban (phakeolis) rather than skaranikon on feast days. 


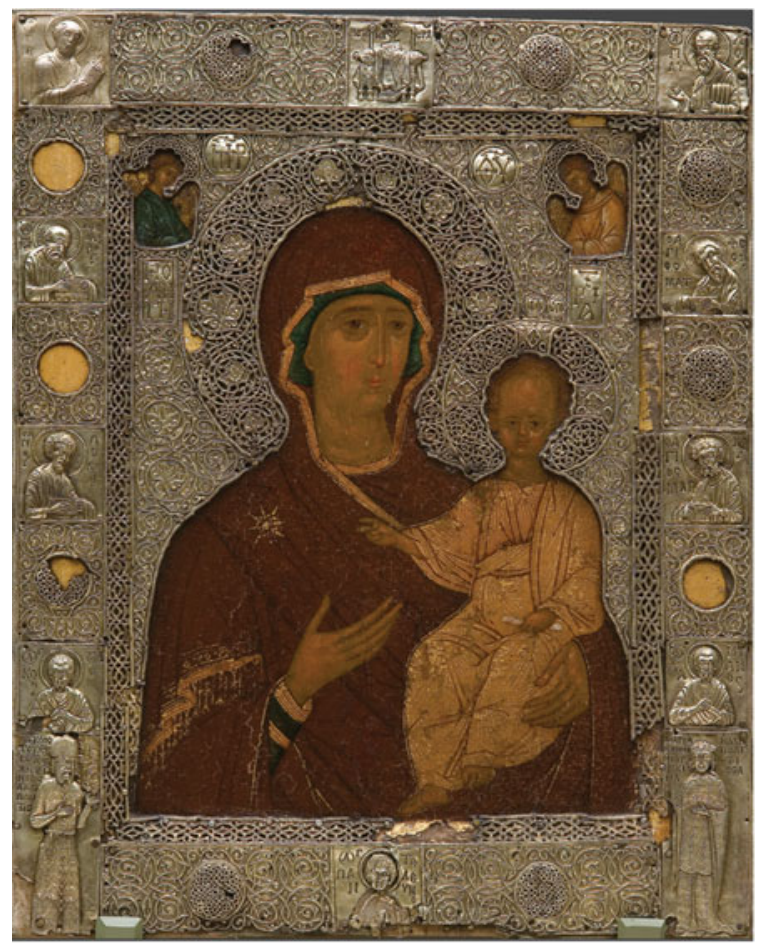

Fig. 4. (Colour online) Icon of the Hodegetria with silver repousse frame showing Constantine Akropolites and his wife Maria as donors, end of $13^{\text {th }}$ or beginning of $14^{\text {th }}$ century, Tretyakov Gallery, Moscow. Photograph copyright The State Tretyakov Gallery.

Pseudo-Kodinos (Fig. 4, Fig. 5). ${ }^{53}$ Unfortunately, Constantine is labelled by his inscrip-

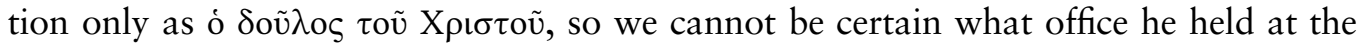
time of the icon's manufacture around $1300 .{ }^{54}$ Roughly contemporaneous with the portraits in the Lincoln College Typikon is the image of the megas doux Alexios Apokaukos in the frontispiece of the Hippocrates manuscript in Paris (Fig. 6). ${ }^{55}$ Dating between his elevation to the office in 1331 and his assassination in 1345, the portrait shows him wearing a skaranikon with a slightly bulbous crown of red material. The enthroned emperor shown on the front of the hat is framed under a pearl-edged trefoil arch. Pseudo-Kodinos stipulates such pearl embroidery only for the skaranikon of the megas domestikos (rank 4)-but in this case it is to frame a standing (not enthroned) portrait of the emperor, flanked by angels in roundels. ${ }^{56}$

53 A. Bank, Iskusstvo Vizantii v sobraniiakh SSSR, 3 (Moscow 1977) 159, no. 1010; Parani, Reconstructing the Reality, pl. 76, 332, no. 39; Parani, 'Cultural identity and dress', 109, 133, fig. 8.

$54 \mathrm{He}$ was appointed logothetes tou genikou in 1282, but his rank between c. 1294 and the time of his appointment as megas logothetes in 1305/6 is not recorded. PLP I, 49, No. 520. On the rank of the megas logothetes prior to 1321, see Verpeaux, Traité des offices, 26, 28-29.

55 Paris BN ms gr. 2144, fol. 11r; Spatharakis, Portrait, 148-150, figs. 96-97; C. Förstel in Evans (ed.) Byzantium: Faith and Power, 26-27, cat. no. 2.

56 Macrides et al., Pseudo-Kodinos, 55-51, 345; Verpeaux, De Off., 152. 


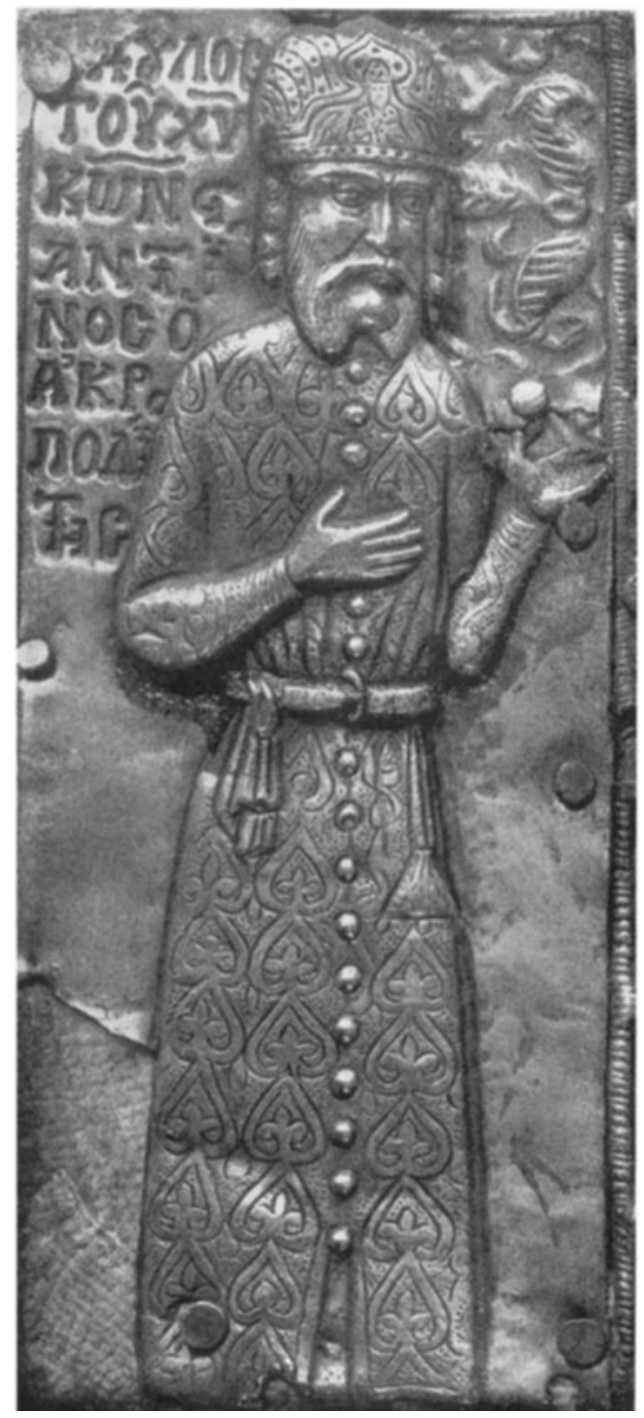

Fig. 5. Constantine Akropolites, detail of silver repoussé icon frame. Photograph after A. V. Bank, Byzantine Art in the Collections of Soviet Museums (Leningrad, 1977), fig. 245.

Finally, Pseudo-Kodinos specifies the medium of the imperial portrait, which varies, like the colour and quality of the skaranikon, according to the rank of the wearer. This is the most critical and intriguing aspect of his list. If one makes the assumption that the more esteemed materials and techniques were used for the higher ranks of courtiers, then one can use the costume list of Pseudo-Kodinos to reconstruct a partial hierarchy of media for the Late Byzantine era. For those who wear the red-and-gold skaranika,

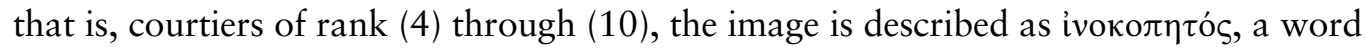




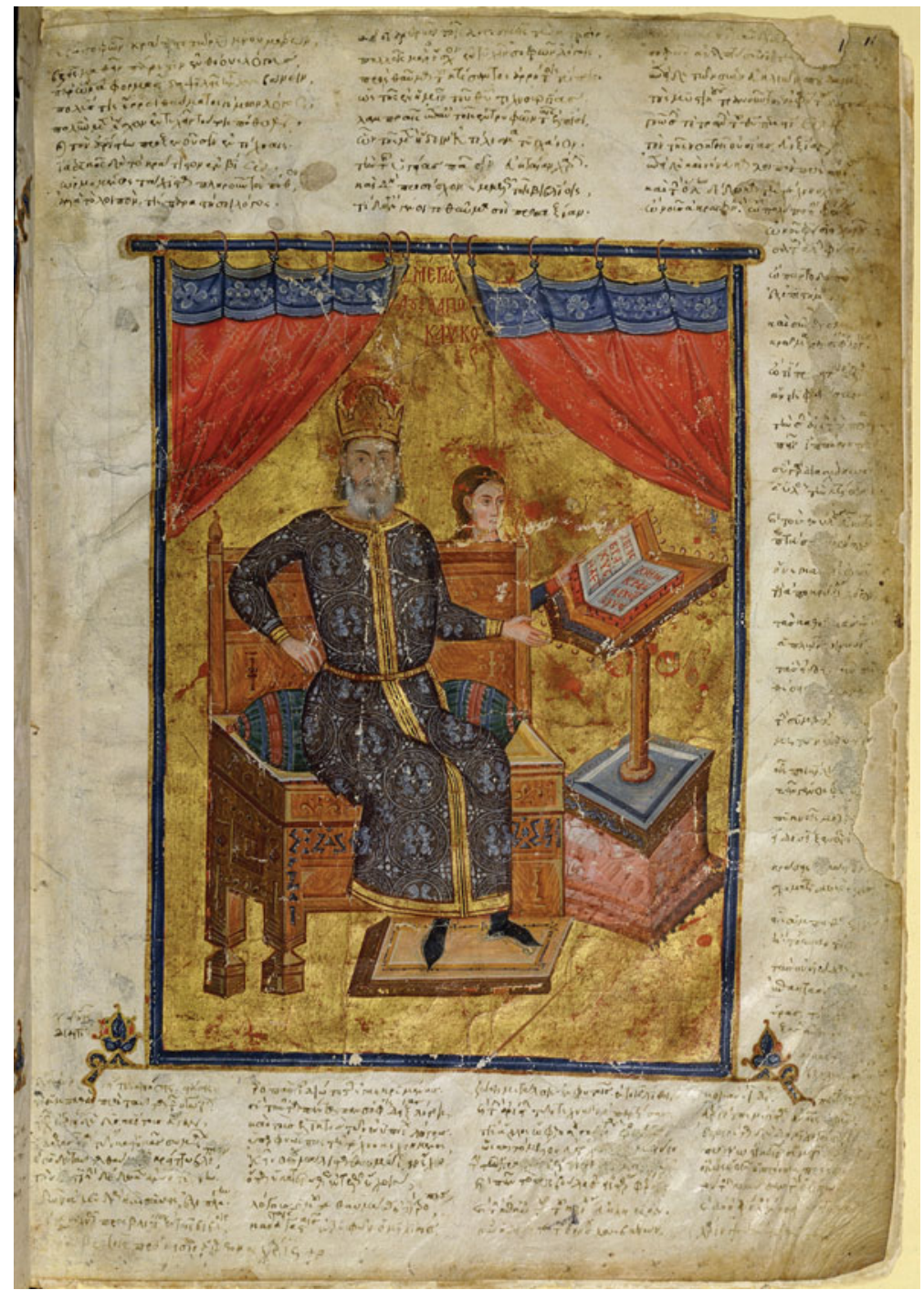

Fig. 6. (Colour online) Alexios Apokaukos, Paris Bibliothèque Nationale ms. Gr. 2144, fol. 11r. Photograph: Bibliothèque nationale de France.

Verpeaux glosses as 'finement ciselé. ${ }^{57}$ The word is rare, but it appears (spelled

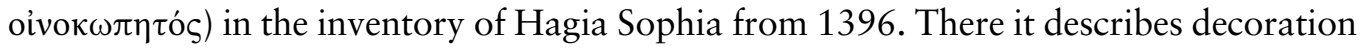
on metalwork: patens, chalices, and the like, frequently with figural imagery. ${ }^{58}$ Given

57 Verpeaux, De Off., 153.15-16.

58 F. Miklosich and I. Müller, Acta et diplomata graeca medii aevi sacra et profana, 6 vols. (Vienna 186071) II, 566-569. See also the comments on this inventory by Hetherington, 'Byzantine and Russian enamels', 131-137. 
the context, it seems most likely that repoussé metalwork is described. ${ }^{59}$ Repoussé as a decorative technique seems to have flourished particularly in the thirteenth and fourteenth century, perhaps in part filling a void created by the decline of cloisonné enamel. The Monastery of Xeropotamou on Mount Athos preserves the will of Theodore Skaranos, dated to c. 1270-1274, which mentions an icon revetment in the technique; ${ }^{60}$ numerous comparable examples survive, such as the repoussé icon frame with the image of Constantine Akropolites wearing the skaranikon. An epigram of Manuel Philes, no doubt intended for inscription on the object it describes, praises a silver panagiarion for

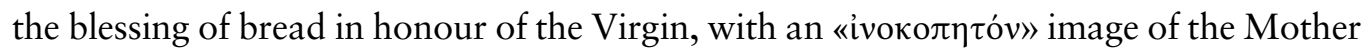
of God at its centre. ${ }^{61}$ Although Pseudo-Kodinos' text does not specify the metal, the parallel descriptions in the Hagia Sophia inventory and in surviving works suggest that gilded silver would have been the material from which the imperial portraits were formed. While the pearls and the angels they encircle drop out of the picture below the

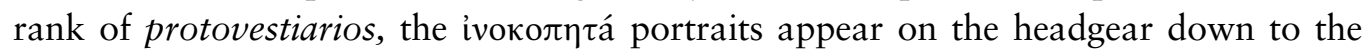
megas stratopedarches, the tenth in order of rank. The change in the pose of the portraits and the elimination of the flanking angels corresponds with the transition from the highest ranks of officials, those with a 'signature' colour marking their mantles and shoes as well as their documents, to those ranks without this distinction. ${ }^{62}$ If the identifi-

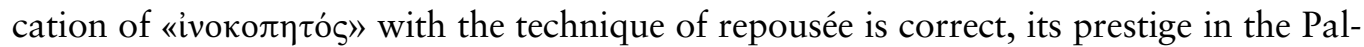
aiologan period is attested by its use-in pure gold-for a reliquary of the true cross preserved in Siena. In the more common medium of silver-gilt, it adorned a number of other prestigious reliquaries created in the early fourteenth century. ${ }^{63}$ It is thus a logical medium for use on the headgear of the more senior ranks of courtiers.

The lower-ranked half of the courtiers who wear the skaranikon with the imperial image wear headgear with the portrait embroidered in gold (or silver-gilt) wire

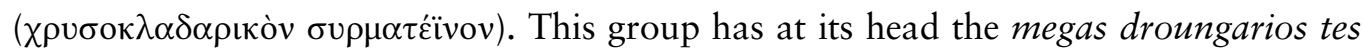
vigles (rank 24), whose skaranikon 'is made of gold-yellow silk and is embroidered with gold wire. It has at the front an image of the emperor seated on an elevated golden

$59 \mathrm{Du}$ Cange, glossing a passage from Pseudo-Kodinos that describes a staff of office with similar

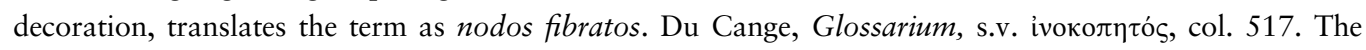
Lexikon zur byzantinischen Gräzität glosses the term as 'mit eingehämmerten Adern', which would seem to imply intaglio rather than relief. LBG, ed. Trapp, 4. Faszikel (Vienna 2001) 710, s.v. Verpeaux's translation, finement ciselé, while less literal, is congruent with the context.

60 Testament de Théodore Skaranos (no. 9), Actes de Xéropotamou, ed. J. Bompaire, Archives de l'Athos III (Paris 1964) 81, 11. 41-42.

61 Manuelis Philae Carmina, ed. E. Miller, II (Paris 1857) 157, no. CXIV. The epigram has recently been discussed by I. Drpić, 'Notes on Byzantine panagiaria', Zograf 35 (2011) 55-56, n. 31.

62 The anonymous verse list of officers draws a similar distinction for the first five ranks, placed in the first

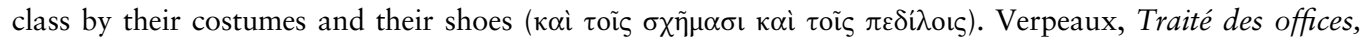
334.26-27.

63 Hetherington, 'A purchase of Byzantine relics', 8-17, figs. 6-14. 
throne and at the back the emperor on horseback. ${ }^{64}$ The same headgear is worn by the courtiers down to rank 48 , the protoierakarios. ${ }^{65}$ Numerous examples of ecclesiastical insignia with gold embroidery that survive from fourteenth-century Byzantium make it possible to envision what such portraits might have looked like. ${ }^{66}$ Because of the relatively high purity of silver needed to draw wires suitable for embroidery, the

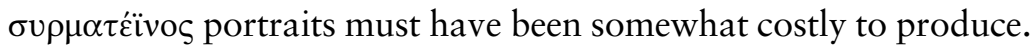

While there is relatively little difficulty in interpreting the medium of the gilded repoussé imperial figures on the skaranika of ranks 4-10 or the gold-embroidered imperial figures worn by ranks $24-48$, the imperial portrait worn by the officials of intermediate rank presents a thornier problem. They are described as having skaranika with the

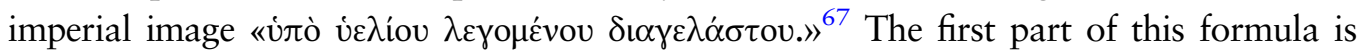

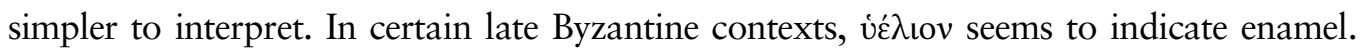
As Paul Hetherington has demonstrated, the normal middle-Byzantine Greek words for enamel, $\chi \dot{v} \mu \varepsilon v \sigma ı \varsigma$, and for enamelled work, $\chi \varepsilon £ \mu \varepsilon v \tau$ tó, all but disappear from texts written after 1204, while the word v́ć $\lambda_{\text {ıov }}$ frequently occurs in contexts that suggest that it served as a lexical replacement. ${ }^{68}$ As late as 1200 , the inventory of the treasury of the Monastery of St. John on Patmos could precisely describe the ornaments of the icon of John the Theologian as $\chi \rho v \sigma o \chi \varepsilon ц \mu \varepsilon v \tau \tilde{\omega} v$-enamelled on gold. ${ }^{69}$ But in 1438, when Sylvester Syro-

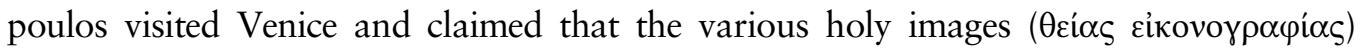
making up the Pala d'Oro were taken from Constantinople, he seemingly had no word to

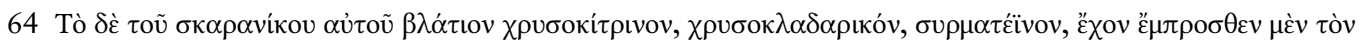

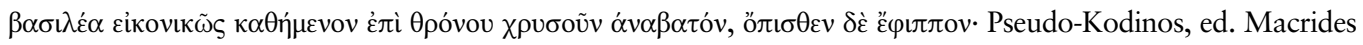

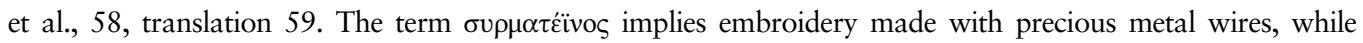
$\kappa \lambda \alpha \pi \omega \tau$ ó $\varsigma$ seems to designate the more usual metallic threads composed of gilded strips wrapped around a silk core; the distinction is discussed by Macrides et al., 329-331. The majority of Byzantine ecclesiastical embroideries are executed with metal-wrapped threads, although some of the finest examples use silver and silver-gilt wire. The author wishes to thank Elena Papastavrou for a helpful discussion of these techniques.

65 Note that according to Pseudo-Kodinos, a turban rather than a skaranikon is worn by ranks 27 (logothetes tou dromou) 28 (protasekretis) 30 (mystikos), 39 (logothetes ton oikeiakon) 40 (megas logariastes), 44 (epi ton deeseon), 47 (logothetes tou stratiotikou), and 49 (logothetes ton agelon).

66 See, for example, the ruler portraits on the Major Sakkos of Photios in Moscow. Hilsdale, Byzantine Art and Diplomacy, 292-295, figs. 5.2-5.5, pl. 10. For secular embroideries from the late medieval Balkans, see B. Cvetković, 'Textiles and their usage in the medieval Balkans: The royal context', in M. Kapustka and W. T. Woodfin (eds.), Clothing the Sacred: Medieval Textiles as Fabric, Form, and Metaphor (Berlin 2015) 33-52.

67 Macrides et al., Pseudo-Kodinos, 54-55; Verpeaux, De Off., 155.

68 The appearance of the term $\chi \cup \mu \varepsilon v \tau \dot{\alpha}$ in the 1449 inventory of the Monastery of the Virgin Eleousa near Strumica, as Paul Hetherington suggests, may be an archaism derived from an older inventory used as a model. L. Petit, 'Le monastère de Notre Dame de Pitié en Macédoine', Izvestiia russkogo arkheologicheskogo instituta $v$ Konstantinopole 6 (1900), 114-152, 118-119; Hetherington, 'Byzantine and Russian enamels', 137. The usual Modern Greek term for enamel, $\sigma \mu \alpha \dot{\alpha} \lambda \tau$, shows no continuity with Byzantine usage.

69 Cutler, 'Industries of art', 578, n. 107; C. Astruc, 'L'inventaire dressé en septembre 1200 du trésor et de la bibliothèque de Patmos: Édition diplomatique', Travaux et Mémoires 8 (1981) 20, lines 4-5. 
describe their medium (ü $\lambda \eta) .{ }^{70}$ The inventory taken of the treasury of Hagia Sophia in Constantinople in 1399 lists several liturgical vestments and vessels adorned with vé $\lambda_{\iota} \alpha$, which would seem to be enamels, and others with $\lambda_{\imath} \theta \alpha \dot{\rho} \rho \iota \dot{v} \varepsilon \lambda_{i} \alpha$, which could be interpreted as glass paste gems, as Paul Hetherington has suggested. ${ }^{71}$

If, based on other late-Byzantine texts, we interpret v́c่ $\lambda$ ıov in this context to mean enamel, what does the text mean by further specifying that they are called $\delta \iota \alpha \gamma \varepsilon \dot{\varepsilon} \lambda \sigma \tau \tau_{0}$ ?

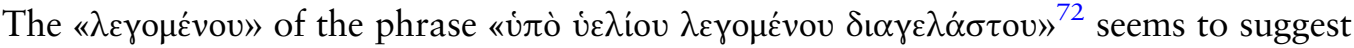
apology for the introduction of a colloquialism. The term appears a further time in the text, where it describes the imperial image on the skaranikon of the logothetes tou geni-

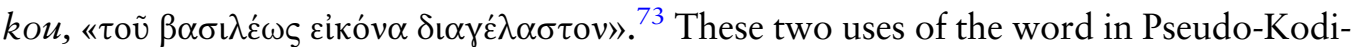
nos are its only known instances in the late-Byzantine period, and in this context it has traditionally been glossed as signifying transparency. ${ }^{74} \mathrm{Du}$ Cange, citing this passage from De Officiis as his sole reference, interprets $\delta\llcorner\alpha \gamma \varepsilon \dot{\varepsilon} \lambda \alpha \sigma \tau \varsigma$ as 'sub vitri specie pellucidi', 75 and the Lexikon zur byzantinischen Gräzität similarly translates $\delta \mathrm{\iota} \alpha$ ' $\lambda \alpha \sigma \tau \sigma \varsigma$ in this instance as durchscheinend (albeit with a query). ${ }^{76}$ These translations, however, do not seem adequate to explain its specific use in this passage and its relation to the imperial portrait. The word itself comes from $\gamma \varepsilon \lambda \alpha \dot{\alpha} \omega$, to smile or laugh at something, and the sense of transparency could be argued from its application to smiling weather or smiling seas. ${ }^{77}$ On the other hand, the lexicon of pseudo-Zonaras makes plain that the word and those formed from it preserved its primary sense of mockery into the middle-Byzantine period. ${ }^{78}$ Homer's phrase " $\rho \gamma \alpha \alpha \varepsilon \lambda \alpha \sigma \tau \alpha$, describing the 'laughable affair' of Aphrodite and Ares caught in the net of Hephaistos, is glossed by Eustathios of Thessalonike, who connects it to the verbal forms $\gamma \varepsilon \lambda \tilde{\omega}$ and $\gamma \varepsilon \lambda \alpha \dot{\alpha} \zeta \omega{ }^{79}$ The tenth-century bishop Leo of Synada uses the same term, $\gamma \varepsilon \lambda \alpha \sigma \tau$ ós, to ridicule a bureaucratic underling who has

70 P. Hetherington, 'Byzantine and Russian enamels', 136; Hetherington, 'Byzantine cloisonné enamel', 197, n. 110; Syropoulos, 'Mémoires', 222-223.

71 Miklosich and Müller, Acta et diplomata, II, 566-570; Hetherington, 'Byzantine and Russian enamels', 135-136. A similar usage of vé $\lambda_{\iota} \alpha$ occurs in the Diataxis of Michael Attaleiates: J. Thomas and A. Constantinides Hero (eds), Byzantine Monastic Foundation Documents, 5 vols. (Washington, D. C. 2000) I, 357,371 n. 32 .

72 Macrides et al., Pseudo-Kodinos, 54-55; Verpeaux, De Off., 155.

73 Macrides et al., Pseudo-Kodinos, 56-57; Verpeaux, De Off., 157.

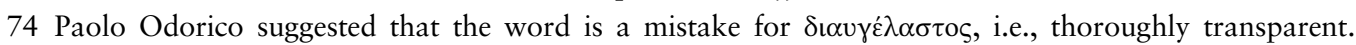

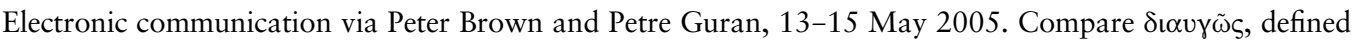
by the Lexikon zur byzantinischen Gräzität as «glänzend, hell, klar.» Lexikon zur byzantinischen Gräzität, ed. Trapp, 2. Faszikel (Vienna 1996) 375, s.v. As others have noted, the vocabulary of Pseudo-Kodinos' section on costume is particularly difficult, and features a number of hapax legomena.

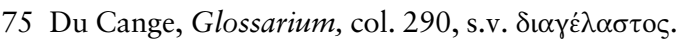

76 Trapp, Lexikon zur byzantinischen Gräzität, 2. Faszikel (Vienna 1996) 355, s.v.

77 Thus, Theocritus, Historia Plantarum, 8.2.4, cited in Liddell, Scott, Jones, Greek-English Lexicon, s.v.

78 Johannis Zonarae Lexicon, ed. J. A. H. Tittman (Leipzig 1808, repr. Amsterdam 1967) 424, s.vv.

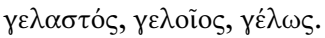

79Eustathii archiepiscopi Thessalonicensis commentarii ad Homeri Odysseam, ed. G. Stallbaum, 2 vols. (Leipzig 1825,1826, repr. Hildesheim 1970) I, 300. 
written to him with inadequate deference as 'more of a joke than a joker. ${ }^{80}$ The only text apart from Pseudo-Kodinos to use the form $\delta\llcorner\alpha \gamma \varepsilon \dot{\varepsilon} \lambda \alpha \sigma \tau o \varsigma$ (-ov), the sixth-century (and much reworked) life of St. Symeon Stylites the Younger, uses it in two places to designate an object of ridicule: in one instance a fearsome beast that is defeated and pub-

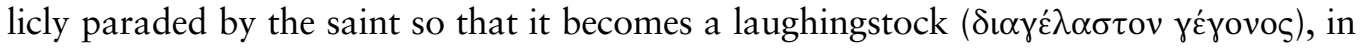
the other a man suffering from alopecia, who is derided by his neighbours ( $\delta\llcorner\alpha \gamma \varepsilon \dot{\lambda} \lambda \alpha \sigma \tau$ o

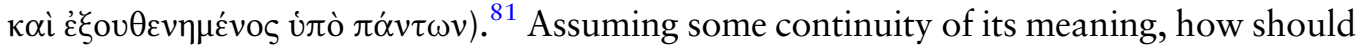
we account for such a word in an utterly serious work on court ceremonial?

Both modern editions of Pseudo-Kodinos accept that the image being described by

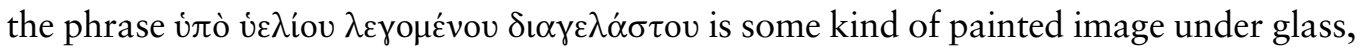
but parallel usages suggest $\delta ı \alpha \gamma \dot{\varepsilon} \lambda \alpha \sigma \tau$ oৎ must mean something other than 'transparent'. Within the semantic field suggested in other contexts, 'an object of mockery', I would propose a further refinement, translating $\delta\llcorner\alpha \gamma \varepsilon \dot{\lambda} \lambda \alpha \sigma \tau \mathrm{s}$ as 'mock' in the sense of 'mock turtle soup.' In pursuing this rendering, my intention is to grasp at hints that the author of Pseudo-Kodinos' treatise was aware that the technique was a substitute for another, more valuable one. Mock turtle soup was an economizing response to the shortage and expense of real sea turtles after decades of their decimation for the dining tables of Europe. Lewis Carroll's Mock Turtle, with the head and tail of a calf, of course alludes to the main ingredients of mock turtle soup (Fig. 7). ${ }^{82}$ The other notable attribute of Carroll's character is his continuous weeping. When Alice asks the Mock Turtle about his tears, he explains to her that he is mourning his youth, when he was a real turtle. ${ }^{83}$ The poignancy of the ersatz brings us back to Nikephoros Gregoras, who records his dismay at the poverty into which the Byzantine Empire had fallen by the time of John VI and his coronation with gems of glass paste:

The palace was so poor that there was in it no cup or goblet of gold or silver; some were of pewter, all the rest of clay... most of the imperial diadems and garb showed only the semblance of gold and jewels;... they were of leather and were but gilded... or of glass which reflected in different colors; only seldom, here and there, were precious stones having a genuine charm and the brilliance of pearls... To such a degree the ancient prosperity and brilliance of the Roman Empire had fallen, entirely gone out and perished, that, not without shame, I tell you this story. ${ }^{84}$

80 Leo of Synada, letter 28, line 15, ed. M. P. Vinson, The Correspondence of Leo, Metropolitan of Synada and Syncellus, Corpus Fontium Historiae Byzantinae XXIII (Washington 1985) 44.

81 E. Trapp (ed.), Lexikon zur byzantinischen Gräzität, 2. Faszikel (Vienna 1996) 355, s.v.; P. van den Ven (ed.), La vie ancienne de S. Syméon Stylite le Jeune (521-592) (Brussels 1962) I, 142, 172.

82 I. Beeton, Household Management (London 1861) 88-89; L. Carroll, Alice's Adventures in Wonderland (London 1866) 137.

83 Carroll, Alice's Adventures in Wonderland, 139-140.

84 Gregoras, II, 788-789; English translation in A. A. Vasiliev, History of the Byzantine Empire, 2nd edn (Madison 1952) 680. 


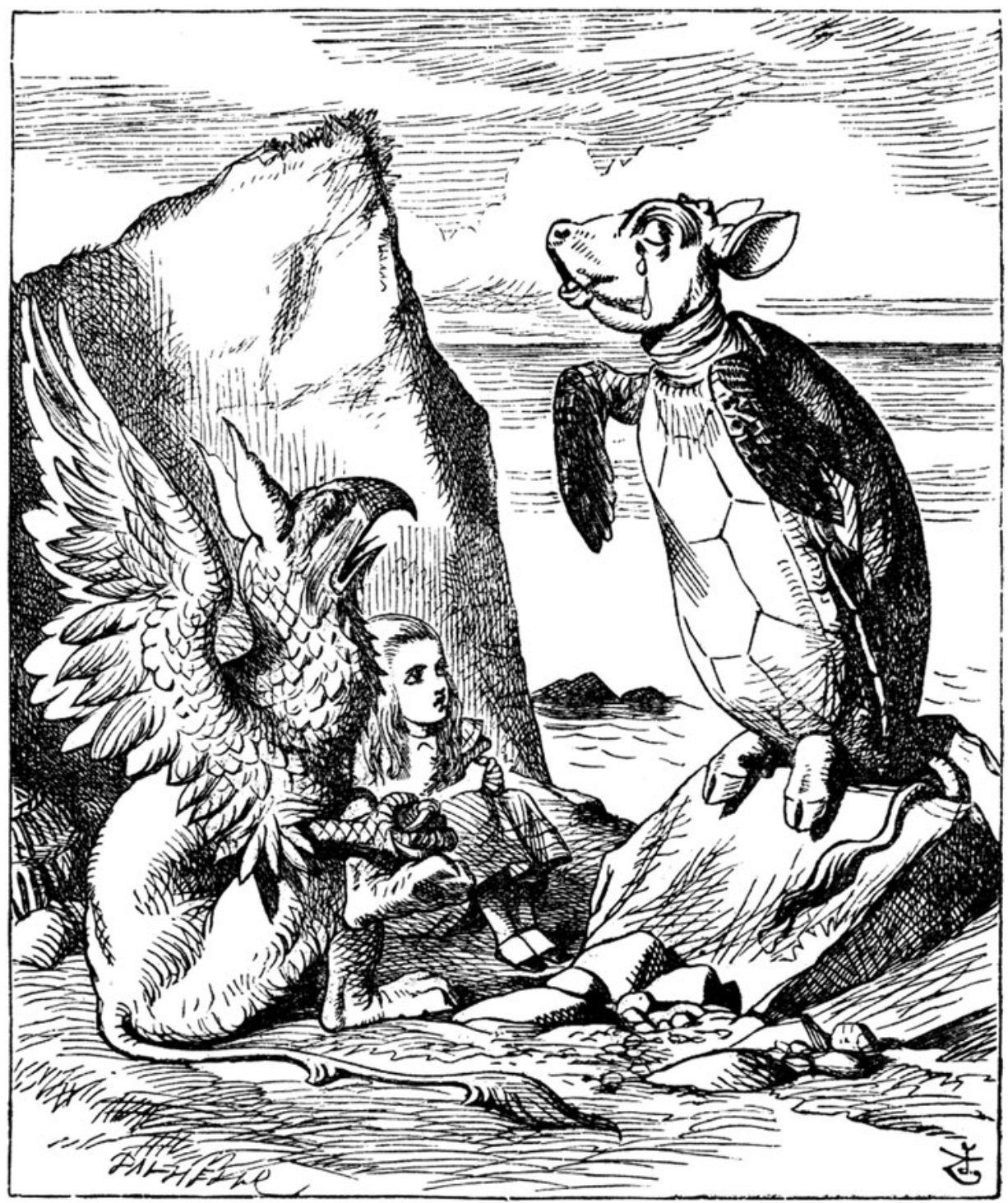

Fig. 7. John Tenniel, Alice with the Mock Turtle and Gryphon, illustration from Lewis Carroll's Alice's Adventures in Wonderland, (London, 1866), 141.

Gregoras' passage in turn served as inspiration for Constantine Cavafy's twentieth-century poem 'Of Coloured Glass' ('A $\pi$ ó v $\alpha \lambda i ́$ ' $\chi \rho \omega \mu \alpha \tau \iota \sigma \tau o ́)$, in which he described the use of these substitute materials as:

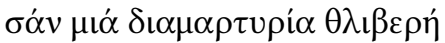

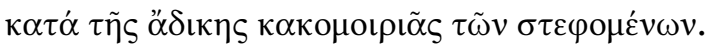

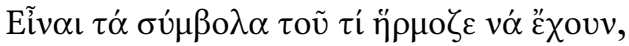




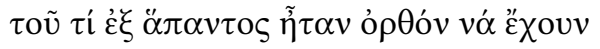

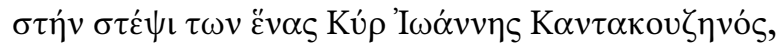

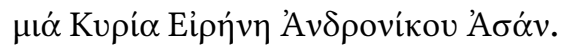

a sad protest against

the unjust misfortune of the couple being crowned, symbols of what they deserved to have, of what surely it was right that they should have at their coronation-a Lord John Kantakuzinos, a Lady Irini, daughter of Andronikos Asan. ${ }^{85}$

Cavafy, in fact, inverts the shame expressed by Gregoras, seeing the use of the ersatz rather as an insistence on the dignity proper to the imperial office and the nobility of its occupants, even in a time of political and economic collapse. The agenda of PseudoKodinos' treatise aligns with Cavafy's view: the good order of imperial ceremonial and the use of techniques that resemble the court's traditional luxury goods help to keep up the appearance of imperial taxis despite constricted means. An important clue to this is

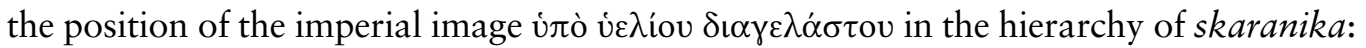
it belongs to ranks lower than the previous-metal repoussé images, but to ranks higher than those with the gold-embroidered images. The portraits in verre églomisé thus rank lower than one would expect for the true cloisonné enamels that they evoke, but higher than images in the (almost certainly) more costly medium of gold embroidery.

The question remains, of course, whether such a mode of thinking about substitute materials and techniques is purely modern, or whether it is supported by evidence from the Palaiologan era. In fact, while evidence of an analogous attitude in the late Byzantine period is scarce, it does exist. One of the fourteenth-century repoussé reliquaries preserved in Siena, containing a relic of St. John Chrysostom, bears an inscription that plays off the saint's epithet to reveal awareness of its own material:

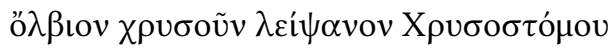

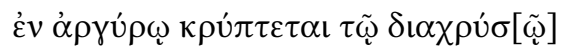

That is to say, 'The blessed golden relic of Chrysostom is hidden in gilded silver. ${ }^{86}$ The way the text is placed on the object-wrapping inconspicuously around the sides of the reliquary-simultaneously hides and advertises the object's real material. Gilded silver, of course, co-existed with gold throughout the Byzantine period, and the two were frequently used interchangeably. One might cite the two staurothekai of Irene Doukaina and her daughter, both from the early twelfth century, the mother's reliquary silver-gilt,

85 K. Kavaphis, Tá Пoı́ $\mu \alpha \tau \alpha$ (Athens 1990) 155; trans. E. Keeley and P. Sherrard, C. P. Cavafy: Collected Poems (Princeton 1975) 128. Republished with permission of Princeton University Press; permission conveyed through Copyright Clearance Center, Inc.

86 Hetherington, 'A purchase of Byzantine relics', 16-17, 18, figs. 16-17. 


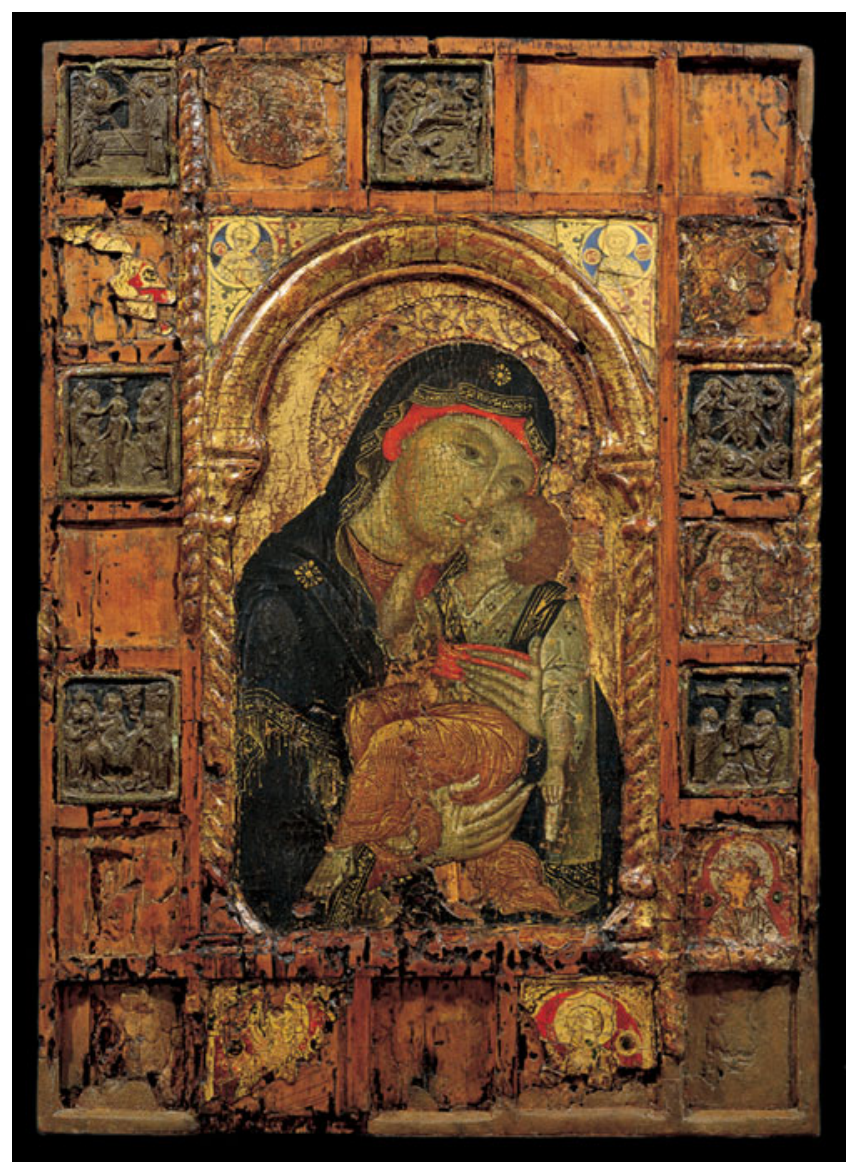

Fig. 8. (Colour online) Icon of the Virgin Eleousa, 14th century, Benaki Museum, Athens. Photograph (C) 2017 by Benaki Museum Athens.

the daughter's of gold. ${ }^{87}$ What seems to be new in the Palaiologan period is the awareness and acknowledgement of the material as something other than what it appears to be.

One might also compare the rather battered icon of the Virgin Eleousa in the Benaki Museum, Athens, which has been attributed to a Byzantine artist perhaps working in fourteenth-century Venice (Fig. 8) ${ }^{88}$ On either side of the arch framing the image are roundels showing the Evangelists Luke and Matthew (Fig. 9). Although the bright colours and gold resemble enamel, the shattered glass immediately betrays the fact that they are, in fact, executed in the cheaper medium of verre églomisé. The icon is framed

87 Cross of Irene Doukaina: A. Frolow in H. R. Hahnloser (ed.), Il tesoro di San Marco Il Tesoro di San Marco, vol. 2, Il Tesoro e il museo (Florence, 1971) 35-37, pl. XXVIII-XXIX, cat. no. 25. Cross of Maria Porphyrogennete: E. Voordeckers and L. Milis, 'La croix byzantine d'Eine', Byzantion 39 (1969) 456-488; J. Lafontaine-Dosogne (ed.), Splendeur de Byzance (Brussels 1982) 152-154, cat. no. O. 21; A. Cutler, 'At court', in R. Cormack and M. Vassilaki (eds.), Byzantium, 330-1453 (London 2008) 115-116, fig. 24. 88 M. Vassilaki in Evans (ed.) Byzantium: Faith and Power, 502-503, cat. no. 305. 


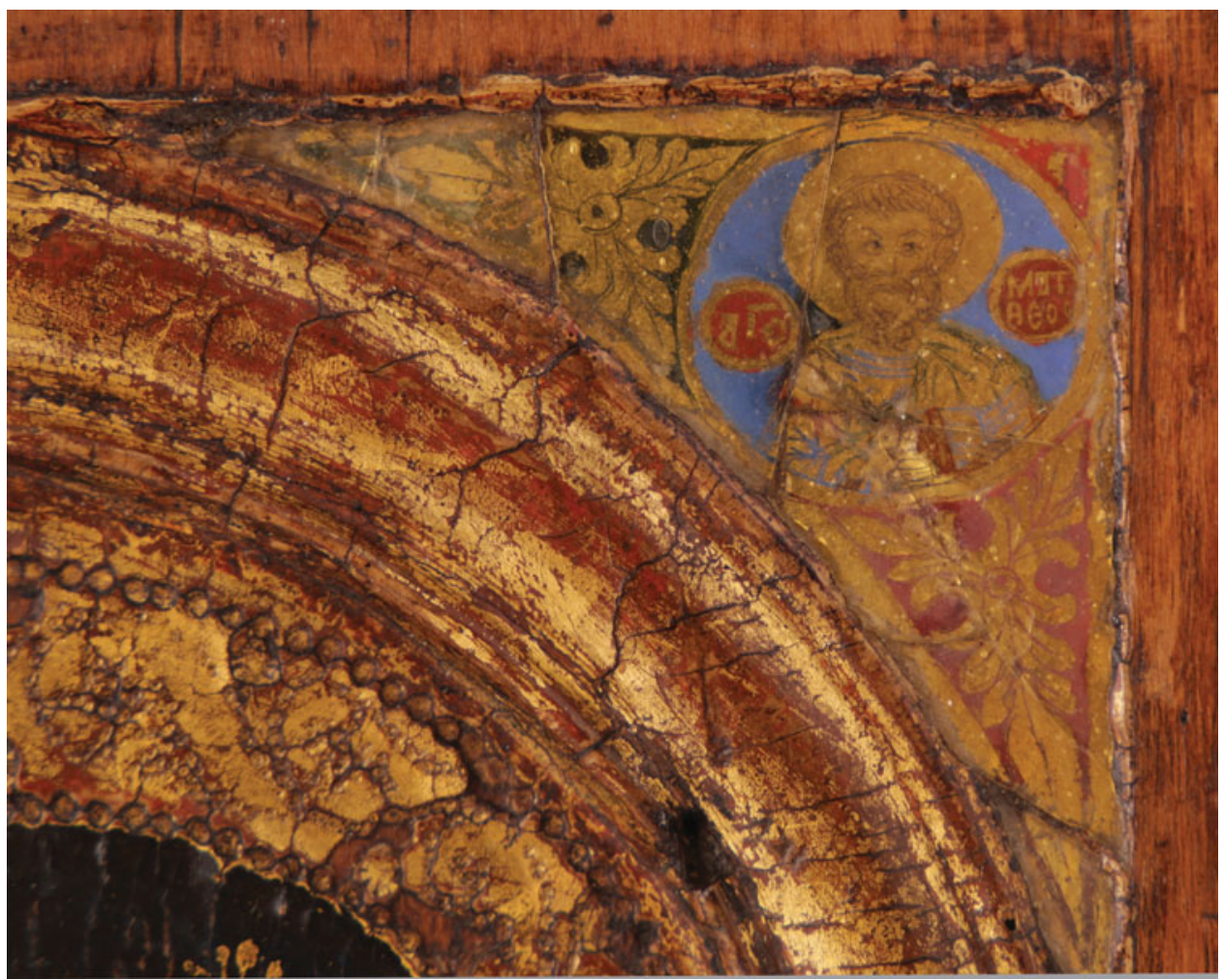

Fig. 9. (Colour online) Icon of the Virgin Eleousa, detail of verre églomisé image of St. Matthew. Photograph ( $) 2017$ by Benaki Museum Athens.

by panels of moulded and painted stucco, imitating carved steatite. These, in turn, alternate with busts of saints, which again imitate enamel-or even, perhaps, imitate verre églomisé substitutes for enamel-but are in fact merely tempera painted on a gilded gesso ground. ${ }^{89}$ The use of so many fictive media in this case seems to be conscious and deliberate, although only our textual sources can point us towards the attitude with which the ersatz was approached in late Byzantium. The same awareness of sleight of hand-evidenced both in Gregoras and by the anonymous author of the epigram on the Chrysostom reliquary-can be discerned in Pseudo-Kodinos' use of the term $\delta\llcorner\alpha \gamma \dot{\varepsilon} \lambda \alpha \sigma \tau$ os.

89 D. Gordon, 'The icon of the Virgin Glykophilousa in the Benaki Museum, Athens (inv. no. 2972): the verres églomisés', in Byzantine Icons: Art, Technique, and Technology, ed. M. Vassilaki, (Heraklion 2002) 211-218. Even on the staurotheke of Cardinal Bessarion preserved in Venice, the figural panels of Constantine and Helena flanking the cross are reverse-painted on rock crystal panes. H. Klein, 'Die Staurotek Kardinal Bessarions: Bildrhetorik und Reliquienkult im Venedig des späten Mittelalters', in C. Märtl and C. Kaiser (eds.), Inter latinos graecissimus, inter graecos latinissimus. Bessarion im Wechselspiel kultureller Integration (Berlin 2013) 252, fig. 10. 
In the midst of describing the skaranikon appropriate to each rank, Pseudo-Kodinos indulges in a remarkable digression on its ancient genealogy. He describes its transmission from the Assyrians to the Persians through the conquests of Cyrus, and thence through Alexander the Great to the Roman Empire, whence it passed by descent to the Byzantine emperors. ${ }^{90}$ While Pseudo-Kodinos' account of the origins of the skaranikon is clearly spurious, its superficial resemblance to the so-called korymbos, the bulbous form that adorns the crown worn by certain Sasanian rulers, may have suggested to an observant eye an origin in the ancient Near East. ${ }^{91}$ As Maria Parani has pointed out, this imaginative grafting of the then-recently codified headgear of the 'Romans' onto the root stock of the ancient empires of the East situates the fourteenth-century order the more firmly in the divinely ordained flow of history. ${ }^{92}$ It is striking, however, that this emphasis placed by Pseudo-Kodinos on an (invented) historical lineage is coupled with a clear awareness of the extent of the changes in court ritual. Far from attempting to gloss-over discontinuities, the author goes out of his way to highlight such ruptures, often using $\pi \dot{\alpha} \lambda \alpha$, 'of old', or $\pi \rho$ ó $\varepsilon \rho \rho v$, 'formerly', to signal differences between past practice and the fourteenth-century present. ${ }^{93}$ This tension between emphasis on the longue durée and on the changing vicissitudes of the empire is highlighted in other ways in the text, notably in Pseudo-Kodinos' discussion of the symbolism of the emperor's own insignia:

By carrying the cross the emperor shows his faith in Christ... by his black sakkos, the mystery of the imperial office; by the earth which, as we said, is called akakia, that he is humble, as he is mortal, and that he is not to be proud or arrogant because the imperial office is so exalted; by the handkerchief, the inconstancy of his office and that it passes from one person to another; by the sword, authority. ${ }^{94}$

Far from asserting an invincible and immutable imperial power, Pseudo-Kodinos emphasizes the unpredictability of imperial succession. One can see in this a kind of microcosmic view of the same attitude writ large in the excursus on the skaranikon. The decoration of the hat may economize, but its form lays claim to a legacy of greatness.

90 Macrides et al., Pseudo-Kodinos, 148-151; De Off., ed. Verpeaux, 205-207. The passage is discussed in Macrides et al., Pseudo-Kodinos, 356-357.

91 Persian silver vessels showing this Sasanian crown type are preserved in collections in Russia and might have circulated via Byzantine Constantinople. See B. Marshak and M. Kramarovskii, eds., Sokrovishcha Priob'ia, exhibition catalogue, Hermitage Museum (St. Petersburg 1996). On the so-called korymbos, see M. P. Canepa, The Two Eyes of the Earth: Art and Ritual of Kingship between Rome and Sasanian Iran, (Berkeley 2009) 108, 193-196.

92 Parani, 'Cultural identity and dress', 122-123.

93 Macrides, “The reason is not known”, 320-326; Macrides et al., Pseudo-Kodinos, 12-13. Macrides does not, however, read these passages as betraying awareness of decline.

94 Macrides et al., Pseudo-Kodinos, 140, trans. 141, 347-348; see also G. Dagron, 'From the mappa to the akakia: symbolic drift', in H. Amirav and B. ter Haar Romeny (eds.), From Rome to Constantinople: Studies in Honour of Averil Cameron (Louvain and Paris 2007) 203-220. 
By placing what was in fact a rather recent version of court headgear within a genealogy of empires, Pseudo-Kodinos foregrounds the essential tension between the grand ideological claims of the empire's central place in history and its vastly reduced state in the mid-fourteenth century.

Given the particular role the skaranikon plays in the text in situating the emperor and his retinue in this historical sequence of hegemonic powers, it is significant that the images of the emperor are not merely said to be in painted glass, but rather 'mock enamel', reflecting an awareness of what the material ought to have been under better circumstances. The medium of verre églomisé is thus more than merely a stopgap measure; it is rather an assertion of continuity with the empire's past era of hegemony. If this reading is correct, the attitude towards the ersatz expressed in Pseudo-Kodinos is in fact closer to that of Cavafy's poem than it is to the open lamentation of Gregoras: the substitute medium of painted glass is not so much meant to deceive, as to stand as 'symbols of what they deserved to have.' 